\title{
The Needs Analysis of English Preparatory School Instructors Towards Professional Skills in Higher Education
}

\author{
Polat Erdoğan ${ }^{1, *} \&$ Mehmet Gürol ${ }^{2}$ \\ ${ }^{1}$ School of Languages, İstanbul Sabahattin Zaim University, İstanbul, Turkey \\ ${ }^{2}$ Faculty of Education, Y1ldız Technical University, İstanbul, Turkey \\ *Correspondence: School of Languages, İstanbul Sabahattin Zaim University, Halkalı, İstanbul, 34303, Turkey. \\ E-mail: polat.erdogan@izu.edu.tr
}

Received: January 25, 2021

Accepted: February 13, $2020 \quad$ Online Published: February 16, 2021

doi: $10.5430 /$ jct.v10n1p56

URL: https://doi.org/10.5430/jct.v10n1p56

\begin{abstract}
Many factors affect providing high-quality English education and rendering it sustainable. One of these factors is undoubtedly ensuring the professional development of the English language instructors. An important way to guarantee professional development is through needs analysis. Needs analysis is of utmost significance in determining the professional skills that English preparatory instructors require to develop and taking the necessary steps. In this regard, the aim of the study is to determine the professional skills that these instructors need to develop in higher education. Qualitative research method was used in the research to unearth the opinions, thoughts, views and feelings of instructors on professional skills to be improved. Since the research covered only one unit of a higher education institution, a holistic single case design was preferred. Participants included English preparatory school instructors, administrators, students, and senior members of the Faculty of Education. Convenience and criterion sampling techniques were used in the selection of the participants. In the study in which interview technique was used, an interview form was implemented in order to ascertain the professional skills. The data collection process was carried out over the course of eight weeks. Descriptive analysis and content analysis techniques were used in data analysis. While the opinions of the English preparatory school stakeholders were shared via verbatim quotation technique during the descriptive analysis process, the professional skills that English preparatory instructors require to improve were determined via the content analysis of the participants' relevant opinions. As a result of the research, professional skills that these instructors need to enhance were identified.
\end{abstract}

Keywords: Needs analysis, professional skill, English preparatory school instructor

\section{Introduction}

In our globalized world, thanks to professional development, educational institutions change, transform and develop over time. In this way, they compete with each other in terms of the quality of education, use technology more effectively and frequently in classrooms, produce and consume information quickly and their investment and service change dimensions in schooling and so on. In this context, professional development is the element that distinguishes various educational institutions from the others and takes them one step better and further from their current positions in the competitive education world. Therefore, the importance of professional development is increasing day by day due to educational institutions' needs for human resources in quantitative and especially qualitative terms. Hovewer, the first and most important way to ensure professional development is through needs analysis. Needs analysis is the optimum way to identify strength, weaknesses, threats and opportunities in educational institutions and to take necessary precautions to make change, transformation and development continuous. In other words, needs analysis is carried out in order to perpetuate the professional development, to ensure that an institution achieves its goals, to increase efficiency and to compete better.

Needs analysis has different definitions. Brinkerhoff and Gill (1994) define needs analysis as determining the knowledge and skills required for an institution to achieve its goals and objectives. According to another definition (Molenda et al., As cited in Craig, 1996), needs analysis is a practice that aims to understand the nature of performance problems and develop solutions. Noe (1999) states that needs analysis is a procedure that determines 
whether training is required in an institution. Again, one of the most cited needs analysis definitions was made by Brown. According to Brown (1995), needs analysis is the process of information gathering activities. Needs analysis, especially in the field of education, is an integral part of systematic professional development (Brown, 2001). According to the definition of Dudley-Evans and St John (1998), needs analysis is a process to determine the state of an institution or its personnel and the circumstances that bring about this state. In addition to this definition, Pratt (1980) refers to the needs analysis as a process during which various information gathering techniques are used, needs are identified, their necessity is proven and listed in an order of priority. In short, needs analysis is the formal process of finding solutions by identifying the training and development needs at various levels of educational institutions that are paramount in enabling individual or corporate development in the short and long term and rendering this development sustainable in a constantly changing educational environment. One way to better understand this process is to have a look at the historical development of needs analysis.

The history of the needs analysis dates back to the first half of the 20th century. This concept, which is especially mentioned with language teaching, emerged in the 1920s (West, 1994). However, needs analysis became popular in the 1970s and 1980s as a result of studies published in the field of English for General Purposes and English for Specific Purposes (Richterich \& Chancerel, 1980; Munby, 1987). Needs analysis, which is frequently used in the business and industry world today, is also based on the Elementary and Secondary Education Act of 1965, which was implemented in the USA (Witkin, 1984). From 1960 to 1980 in the USA, needs analysis in areas such as health, education and social services was carried out by various institutions and organizations through federal support programs. In 1980s, the support of grant programs for needs analysis was cut, and since then, the quality and quantity of such studies have decreased, but the public and private sector, which understood the importance of needs analysis, have continued to use needs analysis. In summary, needs analysis has emerged as a concept associated with the education community. However, in our developing and changing world, different types of needs analysis are performed in accordance with the structure of different public and private sector organizations (Witkin, 1984). Different types of needs analysis have various purposes, especially in the context of education. These objectives provide a comprehensive overview as to why the needs analysis is carried out.

Needs analysis has many purposes. The most general purpose of needs analysis can be stated as identifying the special needs of institutions and individuals (Brown, 2002). From an educational and professional development standpoint, the needs analysis guides instructors on what to teach and how to teach it in higher education (Salas \& bow-Bowers, 2001). In addition to these, needs analysis in higher education can increase the satisfaction levels of these instructors or students in the institution, reduce the expenses of the institution, or aid in the improvement of quality standards (Bowman, 1987). The important thing here is to be able to ascertain the process between the purpose and the result of the needs analysis with clarity. In other words, the purposes of the needs analysis should be clearly determined (Taylor, O'Driscoll \& Binning, 1998). In this context, Lee and Nelson (2006) explained the aims of needs analysis. Needs analysis studies are conducted with the aim of collecting information about perceived needs. In this way, problems or deficiencies related to knowledge, skills and behavior are detected. Identifying the problem and seeking solutions support cooperation with stakeholders and help the development of needs analysts, human resources specialists, managers, employees, and students. These improvements, in return, affect the institution positively. Depending on the purpose, needs analysis can sometimes be performed on individuals. Nonetheless, the ultimate goal in needs analysis is to ensure the development and change of the institution. All stakeholders involved in the needs analysis process contribute to the improvement of the quality of themselves and their institutions. The important thing in this process is to be able to produce solutions to the problems encountered in accordance with the purpose of needs analysis and to be sure that the methods and techniques used in producing these solutions are valid and reliable (Kaufman et al., 2003).

Needs analysis studies can be carried out by many institutions to achieve different goals in various fields. However, needs analysis is indispensable especially for educational institutions. Educational institutions such as universities are a whole with their vision, mission, academic staff, culture, history, and students. One of the most important elements that hold this whole together is qualified instructors. Needs analysis studies are required to protect the quality of instructors and to ensure continuity in this regard. The first and most important step of professional development is to be able to carry out the needs analysis study in a comprehensive manner in educational institution. Among the most important elements of an educational institution are students, instructors, and education programs. Each of these elements is expected to meet certain quality standards. From this point of view, ensuring the professional development of instructors requires a comprehensive needs analysis study. This requirement is a precondition for ensuring professional development and making it sustainable. Accordingly, there is a need for studies in which the needs of English preparatory school instructors towards professional skills are investigated and 
professional development programs are designed for these needs. English preparatory schools need qualified instructors, students, administrators, and a high-quality English preparatory school program. Furthermore, a qualified English preparatory school can also be possible by making rudimentary needs analyses for instructors along with preparation, implementation, evaluation of professional development programs and making these ameliorations sustainable.

In the light of the information above, the main purpose of this research is to determine the professional skills that English preparatory school instructors require to develop in higher education.

The research seeks answers to the following questions:

(1.) What professional skills do English preparatory school instructors need to develop?

(1.1.) What professional skills do they need to develop towards the planning of education and training?

(1.2.) What professional skills do they need to develop towards the creation of learning and teaching environments?

(1.3.) What professional skills do they need to develop towards the management of the learning and teaching process?

(1.4.) What professional skills do they need to develop regarding assessment and evaluation?

(1.5.) What are the professional skills determined to be developed as a result of the content analysis of the interviews towards professional skills?

\section{Method}

\subsection{The Design of the Study}

In the study, the case study design, which is frequently used in qualitative research, was preferred to unearth the opinions, thoughts, views and feelings of instructors on professional skills to be improved. In such studies, individual, institution, behavioral situations, a program, school, or all other social phenomena can be the subject of research (Yin, 2009). Scholz and Binder (2011) also state that the case study can be used in all situations where the human factor and other environmental factors are investigated. In this study, the needs of the English preparatory school instructors towards professional skills were handled as a holistic single case. Moreover, this study did not aim to make comparisons among the professional development-based needs of instructors working in different types of institutions such as foundation and state universities or different types of language preparatory schools such as Arabic, English, and Turkish. Therefore, a holistic single case design was preferred.

\subsection{Participants}

In this study, interviews were made with five participant groups. These groups are indicated as follows: eight instructors who actively taught at the English preparatory school of a foundation university for at least one year, two administrators who worked at the same unit for at least five years, four attending students, four graduate students, and two faculty members teaching in undergraduate programs whose mediums of instruction were $30 \%$ and $100 \%$ English. In this way, it was aimed to reach a rich source of knowledge and experience (Patton, 2014). A total of 20 participants were interviewed. Although there is no standard for determining the number of participants (Vagle, 2014), it is stated that the ideal number of participants may vary between 5 and 25 (Creswell, 2007). In the selection of the participants, purposive sampling techniques such as convenient and criterion-based sampling were employed. The main reason for the preference of the aforementioned techniques was to add speed, practicality, and a rich source of information into the research.

\subsection{Data Collection Tools}

During the data collection process, interviews aiming to investigate the professional skills were held in eight weeks in the spring semester of the 2018 - 2019 academic year. The Interview Form towards Professional Skills was used as a data collection tool in the study. Also, the interview form preparation process recommended by Yildirım and Şimşek (2013) was followed. In addition, the interview form was prepared by considering the purpose and research questions upon reviewing the literature on professional skills included in Turkish Education Association Teacher Qualification Report (2009), European Commission: Teachers' core competences, requirements and development Report (2011), European Commission: Supporting teacher competence development Report (2013), Ministry of National Education: Subject Area Competencies for English Teaching Profession Report (2015), Ministry of National Education: Generic Competencies for Teaching Profession Report (2017) and Turkey Higher Education Qualifications Framework (2018). Finally, sufficient interaction was formed with the participants to ensure internal 
validity and the data were confirmed. At the same time, cooperation was made with another researcher who is an expert in the field of ELT during the descriptive and content analysis procedure of the data and the internal validity of the research was intended to be increased by including the researcher triangulation. Moreover, detailed descriptive analysis and purposive sampling techniques in accordance with the nature of the research were included so as to ensure external validity. Last but not least, two ELT experts and two curriculum development specialist were interviewed before and after the pilot study, and the interview form was finalized in order to ensure internal and external reliability.

\subsection{Data Analysis}

In this study, descriptive and content analysis techniques were used in analyzing qualitative data with the aim of summarising the informational contents with respect to the research questions. The descriptive analysis presented the data to the reader with direct quotations by adhering to the original form of the data based on a predetermined framework. The content analysis presented the data to reader with certain codes, categories and themes by quantifying and analyzing the presence, meanings and relationships of them. While direct (verbatim) quotation technique was used during the descriptive analysis process, the inductive approach was adopted and the open, axial, and selective coding sequences supporting this approach were followed in the content analysis process (Elo \& Kyngäs, 2008). Accordingly, the audio files recorded as a result of the interviews were converted into transcripts. The codes were created by reading the transcripts repeatedly, and then temporary categories were determined. Thematic coding of the temporary categories was made by establishing a code - category relationship and the finalized themes were reached. Lastly, data were arranged, analyzed, interpreted, and reported in light of the finalized themes.

\section{Results}

In this section, an answer is sought for the following research question along with the pertinent sub-problems specified in the introduction: "What professional skills do English preparatory school instructors need to develop?". In this context, interviews were made with various stakeholders such as English preparatory school instructors, administrators, students, graduates, and faculty members of different programs with English medium of instruction. Descriptive analysis and content analysis techniques were used in the analysis of the data collected using the interview technique. While stakeholder opinions, which were transformed into text via descriptive analysis, were included by means of verbatim quotation, the relationship between code, category and theme was established by following open, axial, and selective coding order of the views via content analysis. In this way, 20 professional skills that English preparatory school instructors need to improve were identified.

\subsection{Descriptive Analysis of Views towards Professional Skills}

The views towards the professional skills that English preparatory school instructors need to develop were analyzed under four headings such as the planning of education and training, the creation of learning and teaching environments, the management of learning and teaching process, and assessment and evaluation. As part of the verbatim quotation process, following codes were used such as GS for English Preparatory School Graduate Student, PS for English Preparatory School Student, EI for English Preparatory School Instructor, A for English Preparatory School Administrators, FM for Members of Education Faculty.

\subsubsection{Views Towards the Planning of Education and Training}

In this part, an answer is sought for the following research question: "What professional skills do English preparatory school instructors need to develop towards the planning of education and training?". In the analysis of the relevant views, four professional skills that need to be developed were ascertained as the ability to prepare a lesson plan appropriate to the students' language levels, the ability to take the individual differences of students into account in planning, the ability to adapt the course material in planning, and the ability to associate lessons with daily life in planning. Participants' relevant views are as follows:

... (The instructor) needs to study on how to teach the lesson beforehand. Students need to have an idea, a map, or a plan in their minds on how to learn the subject. The teacher must proceed by sticking to this plan... (PS4).

... There should be comprehensive activities that can appeal to different types of intelligence in planning. Students' development levels, interests, abilities, and individual differences should be taken into consideration. The ability to plan activities in a context close to daily life. I think every instructor should 
possess these skills and they should be developed as part of every in-service training program... (EI8).

... Adaptation of the educational content to the level and interest of the student... Knowing the students before planning the process and mastering their learning traits... (EI6).

... For example, we publish a university newspaper every week as a classroom. Some of our friends organize a conversation club event. In this way, students can write and speak about current events in English. This contributes greatly to improving their English. But only a few teachers do this. It takes extra time, but I think such activities should become widespread. Our instructors should improve these skills as well ... (EI5).

\subsubsection{Views Towards the Creation of Learning and Teaching Environments}

In this part, an answer is intended to be given to the following research question: "What professional skills do English preparatory school instructors need to develop towards the creation of learning and teaching environments?"'. In the analysis of the pertinent views, four professional skills that need to be developed were identified as the ability to create environments where students can use English interactively in the lesson, the ability to create learning environments where students can use English outside of the classroom, the ability to create learning environments that support students to develop language learning strategies, and the ability to create democratic classroom environments in English teaching. Participants' relevant views are as follows:

... We dwell on being student-centered all the time. The student should feel safe and participate in the lesson. The lesson should be communication-oriented. If you can achieve that, you are good at this profession... (EI1).

... The classroom is not the only place where effective learning can take place. The classroom can even be boring at times. ... We have a speaking club, a debate club, a music club. Many English events are organized in these clubs. There are also seminars. In some classes, our friends even publish a school newspaper. We should have been involved in these activities outside of the classroom. I think it will be useful. We would have spoken and practiced English outside of the classroom as well... (GS2).

... Also, we should be given tips on how to learn English. How can we memorize words more easily? How can we understand strangers better? How can we speak more fluently? They should help with this... (PS2).

... (The instructor) should be able to create a democratic environment. The ability to create an accessible, encouraging, functional and student-centered atmosphere that encourages innovation... (EI6).

\subsubsection{Views Towards the Management of the Learning and Teaching Process}

In this part, an answer is aimed to be given at the following research question: "What professional skills do English preparatory school instructors need to develop towards the management of the learning and teaching process?" In the analysis of germane views, eight professional skills that needed to be improved were specified as the ability to keep student motivation at an optimum level for learning in English teaching, the ability to use learning management systems, the ability to help students in need of special education, the ability to conduct action research, the ability to work in collaboration with colleagues, the ability to identify students' needs towards learning English, the ability to provide and maintain discipline during the lesson and the ability to use lesson time effectively. Participants' relevant views are as follows:

... The ability to attract students' attention and increase their interest in the lesson. The ability to motivate them. Because the preparation program is very intense. There are 5 or 6 hours of lessons every day. 28 hours a week. Lessons last 10 months without a semester break. The students are tired, bored, and distracted. The ability to motivate them attract them into the lesson must be developed... (EI4).

... It is necessary to follow technology and new trends in order for the process to be healthy, permanent and effective. Teachers who can keep up with them achieve success with their classes. That is why it is important to be able to use learning management systems... (EI3).

... I had a student who had speech difficulties. But he was very clever. I think his problem was articulation. The boy could not speak with the correct pronunciation. He did not like this situation either, I am sure. I wish I could help him. Such students can also be in preparation. After all, $80 \%$ of the students go to preparatory school. These students should be helped. At least they should be directed to the right treatment centers... (FM2). 
... I care very much about doing research. Action research, which we know from the master's degree, must be learned, applied. An observation I made with my classmate from graduate school last semester showed us that students do not complete workbooks. We also made a decision. We had the workbook done in class for 30 minutes a week. In this way, the materials were used more effectively. We are considering the same for LMS... (EI2).

... Ability to collaborate with colleagues. In what areas? Such as classroom management, exam coordination, material preparation, coordination with administrators, ability to use technology and especially learning management systems. In fact, in all areas in general. They must help each other in these matters. Senior instructors can share their skills and experiences with others. They should develop this skill... (A2).

... Instructors should get to know the students in the classroom well in order to actualize effective learning. They must have enough knowledge about their students. If necessary, they should also be able to do a research for this... (PS4).

... (The instructor) must be self-confident. They must show that they are in control in the classroom environment. They should make it felt, but not too hard... (PS1).

...The ability to use time efficiently. For example, what would happen if I entered each lesson five minutes late and left five minutes early for each lesson? I will tell you. A full 33 hours of lessons are not taught in a module. What happens in a year? I do not even want to think. For this reason, attention should be paid to time management, starting, and ending times of the lesson. They must be punctual. These are things that affect the quality of education and training... (EI6).

\subsubsection{Views Towards the Assessment and Evaluation}

In this part, an answer is aspired to be given to the following research question: "What professional skills do English preparatory school instructors need to develop towards assessment and evaluation?" In the analysis of pertaining views, four professional skills that need to be developed were determined as the ability to designate the appropriate assessment tools for the language skills intended to be assessed, the ability to prepare assessment tools suitable for language levels, the ability to use alternative assessment tools to assess and evaluate language skills, and the ability to provide effective feedback after assessment and evaluation. Participants' relevant views are as follows:

... Assessment and evaluation are very sensitive. Exams towards the skills intended to be assessed should be selected. There is a need for educated and experienced instructors who can use technology... (A2)

... Ability to be aware of the students' levels. The ability to ask questions with difficulty suitable for the level. And of course providing timely feedback... (EI4).

... Sir, usually multiple-choice exams, and optical forms are used in the preparation. I am not saying they should not be used. We all use them. But just using them is not right in my opinion. There are many grading tools. Such as book summary, movie summary, class participation, role play, presentation. These should also be taken into account. I am not saying we should give up traditional methods. But I personally am for innovation and diversity... (EI5).

... I remember my university years. I also studied preparation. We used to have quizzes back then. We could not get any feedback. We could not see where and how we went wrong. In this respect, correct and constructive feedback is very important. I always give feedback to my students about exams and assignments. In this way, they can see their mistakes and correct them. They can improve their English. This skill should be possessed by all instructors. I care about this... (EI1).

\subsection{Content Analysis of Views Towards Professional Skills}

Under this title, an answer is sought for the sub-problem of "What are the professional skills determined to be developed as a result of the content analysis of interviews towards professional skills?" As a result of the content analysis of the views of various stakeholders, one theme, four categories and 20 items were attained. Each item was created to represent a professional skill. In addition, frequency and percentage values indicating the frequency of repetition of each item were calculated. In this way, a list of professional skills consisting of 20 items was created. 
Table 1. Professional Skills List

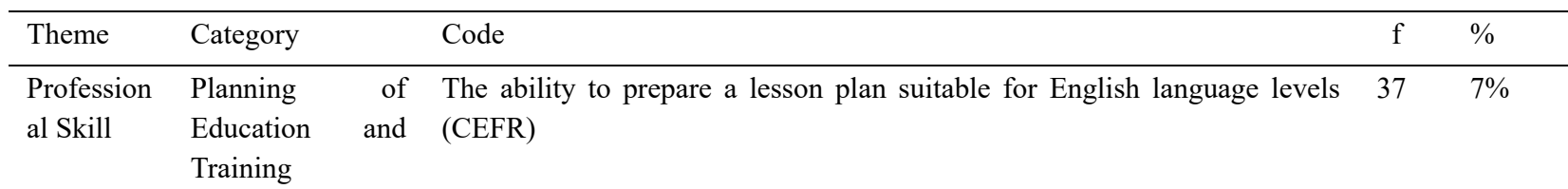

The ability to plan by taking the individual differences of students into $29 \quad 5 \%$ account in teaching English

The ability to adapt the course material in the planning of English teaching $\quad 30 \quad 6 \%$

The ability to associate lessons with daily life in the planning of English $\quad 14 \quad 3 \%$ language teaching

Creation of The ability to create environments that students can use English $47 \quad 9 \%$ Learning and interactively in class

Teaching

Environments

The ability to create learning environments where students can use English $\quad 12 \quad 2 \%$ outside of class

The ability to create learning environments that support students to develop $34 \quad 6 \%$ language learning strategies

The ability to create democratic classroom environments in teaching $28 \quad 5 \%$ English

Management of The ability to keep student motivation at an optimum level for learning in $\quad 27 \quad 5 \%$ Teaching and the English language teaching process

Learning Process

The ability to use learning management systems in the English language $30 \quad 6 \%$ teaching process

The ability to assist students who need special education in teaching $6 \quad 1 \%$ English

The ability to conduct action research in the English language teaching $33 \quad 6 \%$ process

The ability to work in collaboration with colleagues in the English $7 \quad 1 \%$ language teaching process

The ability to identify students' needs for learning English $\quad 31 \quad 6 \%$

The ability to provide and maintain discipline in the classroom in the $51 \quad 9 \%$

English language teaching process

The ability to use lesson time effectively $\quad 20 \quad 4 \%$

Assessment and The ability to designate the appropriate assessment tools for the language $\quad 16 \quad 3 \%$

Evaluation skills intended to be assessed

The ability to prepare assessment tools suitable for language levels

$39 \quad 7 \%$

The ability to use alternative assessment tools to assess and evaluate language skills

The ability to provide effective feedback after assessment and evaluation

Total 
Table 1 shows the results of the content analysis of the interviews towards the professional skills that English preparatory school instructors need to improve. A theme, four categories and 20 professional skills were identified as a result of the needs analysis that was carried out. The frequency of repetition of each professional skill was specified in terms of frequencies and percentages of frequencies. In this context, it was found that the professional skills that need to be developed were categorized under the following dimensions: the planning of education and training, the creation of learning and teaching environments, the management of the teaching and learning process, and assessment and evaluation. Among the relevant skills, it was determined that four skills are part of planning of education and training dimension; four skills belong to the creation of learning-teaching environments dimension; eight skills are associated with the process management dimension and finally, four skills are linked to the assessment and evaluation dimension. In summary, participants' views towards the professional skills that English preparatory school instructors require to develop were presented using descriptive analysis and content analysis techniques in this section and 20 professional skills that need to be developed were identified.

\section{Discussion}

Needs analysis is one of the most fundamental tools used to distinguish between existing skills and desired skills. In this context, researchers define the needs analysis as a necessity to ensure professional development (Bozkurt, et al., 2012; Ekşi \& Aydın, 2012; Koç, 2016). However, it is also essential to take measures that make the needs analysis valid and reliable. In this context, several measures were taken to ensure validity and reliability in the analysis of the needs of the English preparatory school instructors towards professional skills in higher education. These measures can be exemplified as stakeholder triangulation, consultation with ELT experts and program development specialists, reviewing national and international reports in the development of data collection tool, detailed peruse of the relevant literature, conducting pilot studies and triangulation of the data analysis technique. In parallel with the findings of this research, Zein (2017) emphasizes that more than one data collection tool should be used together, especially in determining the needs for professional skills. In recent years, as in this study, there has been an increase in the number of the studies in which multi-data elicitation techniques are used to determine the concrete and abstract needs of English teachers towards professional development (Chen \& Cheng, 2010; Le \& Do, 2012; Chien, 2014; Copland et al., 2014). In summary, triangulation of elements such as participants, resources, data collection tools, data analysis techniques and expert opinions increases the validity and reliability of needs analysis along with adding different dimensions to the research and protecting the research from the prejudices of a single participant group (Dey, 2004; Bryman, 2008; Birks \& Mills, 2011).

In this study, a theme, four categories and 20 professional skills were identified as a result of the descriptive and content analysis of the interviews conducted towards the professional skills that English preparatory school instructors need to develop. In line with the findings of this study, there are several professional skills including providing effective feedback and discipline in the classroom, teaching skills, classroom management, material development along with use of instructional technologies, applications for students needing special education, learning strategies as well as lesson plan preparation, language skills integration and error correction in studies analyzing the professional skills that EFL teachers need to develop (Camuzcu \& Duruhan, 2011; Wichadee, 2012; Copland et al., 2014; Arslan et al., 2019). In addition, 20 professional skills, that were determined to be developed as a result of the needs analysis process in this study, correspond exactly with the findings of national and international reports such as Turkish Education Association Teacher Qualification Report (2009), European Commission: Teachers' core competences: requirements and development Report (2011), European Commission: Supporting teacher competence development Report (2013), Ministry of National Education: Subject Area Competencies for English Teaching Profession Report (2015), Ministry of National Education: Generic Competencies for Teaching Profession Report (2017) and Turkey Higher Education Qualifications Framework (2018).

The focal points of this study have been the analysis of professional skills that instructors need to develop as well as increasing the quality in education and training and making it sustainable. One way to make these possible is through the preparation, implementation, and evaluation of effective professional development programs. In this context, it is stated that EFL teachers who ensure their personal and professional development through various research and professional development programs differ positively from others and they are always one step ahead. (Butler, 2015; Emery 2012; Emery 2012, Le \& Do, 2012; Copland et al. al.2014; Zein, 2015). In particular, professional development programs with need-oriented, authentic and reflective learning activities greatly contribute to the development of professional skills (Tosriadi, et al., 2018; Ryan, 2019). While designing professional development programs, incomplete or erroneous practices implemented especially in analyzing the needs may cause teacher 
trainers to be blamed for or accused of being unwilling and far from taking responsibility to ensure the teachers' professional development. This situation may cause teachers to wear out professionally (Darling-Hammond, 2010; Farrell, 2012; Daniel \& Peercy, 2014).

\section{Conclusion and Recommendations}

As a conclusion, in this research, a comprehensive needs analysis study was conducted in order to determine the professional skills that English preparatory school instructors need to develop. During the research process, a rich data set was obtained by referring to the views of various stakeholders. In the data analysis process, triangulation of the analysis technique was achieved by using descriptive and content analysis techniques together. Accordingly, a theme, four categories and 20 professional skills were identified as the ones that instructors require to develop. Within the scope of the planning of education and training dimension, four professional skills that need to be improved were ascertained as "preparing a lesson plan suitable for language levels, "taking the individual differences of students into account in planning, *adapting the course material in planning, and *associating lessons with daily life in planning. As part of second dimension that is the creation of learning and teaching environments, four professional skills that need to be developed were acquired as "creating environments where students can use English interactively in class, "creating learning environments where students can use English outside of the classroom, *creating learning environments that support students to develop language learning strategies, and *creating democratic classroom environments in English teaching. As for the third dimension that is the management of learning and teaching process, eight professional skills that need to be improved were specified as "keeping student motivation at a optimum level for learning, *in English teaching using learning management systems, *helping students in need of special education, "conducting action research, "working in cooperation with colleagues, *identifying students' needs for learning English, "providing discipline in the classroom and "using lesson time effectively. Finally, with regard to the assessment and evaluation dimension, four professional skills that need to be developed were designated as *determining assessment tools suitable for the language skills to be assessed, "preparing assessment tools suitable for language levels, "using alternative assessment tools in assessing and "evaluating language skills, and providing effective feedback after assessment and evaluation.

Last but not least, some recommendations are listed for program development specialists, teacher trainers and researchers below:

Further research is required to:

- Analyze the needs for professional knowledge, attitudes, and values in addition to the professional skills that need to be developed,

- Conduct needs analyses towards professional skills not only in higher education but also in all levels of education such as primary and secondary education,

- Determine the professional standards of English preparatory school instructors in higher education,

- Design, implement, and evaluate in-service training or professional development programs followed by a needs analysis so as to improve the professional skills of instructors,

- Establish centers such as professional development or lifelong learning in educational institutions in order to ensure continuity in professional development.

\section{Acknowledgements}

This article is generated from the $\mathrm{PhD}$ thesis entitled "Developing a Training Program towards the Professional Skills of the English Preparatory School Instructors in Higher Education" prepared by Polat ERDOĞAN under the supervision of esteemed Prof. Dr. Mehmet GÜROL.

\section{References}

Arslan, S., Mirici, İ., H., \& Öz, H. (2019). In-Service Training Needs of Efl Teachers in Non-Formal Education Settings. Selçuk Üniversitesi Edebiyat Fakültesi Dergisi, 42, 223-244. https://doi.org/10.21497/sefad.675203

Birks, M., \& Mills, J. (2011). Grounded theory: a practical guide. Sage Publications.

Bowman, B. (1987). Assessing your needs assessment. Training, 24(1), 30. 
https://doi.org/10.1016/B978-0-08-033379-3.50012-7

Bozkurt, E., Kavak, N., Yamak, H., Canbazoğlu-Bilici, S., Darıcı, Ö., \& Özkaya, Y. (2012). Secondary school teachers' opinions about in-service teacher training: A focus group interview study. 4th World Conference on Educational Sciences, Barcelona, Spain. https://doi.org/10.1016/j.sbspro.2012.06.093

Brinkerhoff, R. O., \& Gill, S. J. (1994). The Learning Alliance. Pfeiffer \& Co.

Brown, H. D. (2001). Teaching by Principles: An Interactive Approach to Language Pedagogy (2nd ed.). Longman.

Brown, J. (2002). Training needs assessment: A must for developing an effective training program. Public Personnel Management, 31(4), 569. https://doi.org/10.1177/009102600203100412

Brown, J. D. (1995). The Elements of Language Curriculum: A Systematic Approach to Program Development. Heinle and Heinle.

Bryman, A. (2008). Social research methods (3rd ed.). Oxford University Press.

Butler, Y. G. (2015). English language education among young learners in East Asia: a review of current research (2004-2014). Language Teaching, 48, 303-342. https://doi.org/10.1017/S0261444815000105

Camuzcu, S., \& Duruhan, K. (2011). Primary school teachers' needs for in-service training pertaining to the teaching-learning process. e-International Journal of Educational Research, 2(1), 15-29.

Chen, C.W.-Y., \& Cheng, Y.-S. (2010). A case study on foreign English teachers' challenges in Taiwan elementary schools. System, 38, 41-49. https://doi.org/10.1016/j.system.2009.12.004

Chien, C.-W. (2014). Pre-Service elementary school English teachers' learning and reflection through simulated teaching practice and oral interviews. Reflective Practice: International and Multidisciplinary Perspectives, 15(6), 821-835. https://doi.org/10.1080/14623943.2014.944139

Copland, F., Garton, S., \& Burns, A. (2014). Challenges in teaching english to young learners: global perspectives and local realities. TESOL Quarterly, 48(4), 738-762. https://doi.org/10.1002/tesq.148

Creswell, J. W. (2007). Qualitative inquiry and research design: Choosing among five approaches (2nd ed.). Sage Publications.

Daniel, S., \& Peercy, M. M. (2014). Expanding Roles: Teacher Educators' Perspectives on Educating English Learners. Action in Teacher Education, 36(2), 100-116. https://doi.org/10.1080/01626620.2013.864575

Darling-Hammond, L. (2010). Teacher Education and the American Future. Journal of Teacher Education, 61(1), 35-47. https://doi.org/10.1177/0022487109348024

Dey, I. (2004). Grounded theory. In: C. Seale, G. Gobo, J. F. In Gubrium \& D. Silverman (Eds.), Qualitative research practice. Sage

Dudley-Evans, T., \& St John., M. (1998). Developments in English for Specific Purposes A Multi-Disciplinary Approach. Cambridge University Press.

EC. (2011). European Commission: Teachers' core competences: requirements and development Report. Retrieved from https://ec.europa.eu/assets/eac/education/experts-groups/2011-2013/teacher/teacher-competences_en.pdf

EC. (2013). European Commission: Supporting teacher competence development Report. Retrieved from https://ec.europa.eu/assets/eac/education/experts-groups/2011-2013/teacher/teachercomp_en.pdf

Ekşi, G., \& Çapa-Aydın, Y. (2012, May). English instructors' professional development need areas and predictors of professional development needs. Akdeniz Language Studies Conference, Antalya, Turkey. https://doi.org/10.1016/j.sbspro.2013.01.108

Elo, S., \& Kyngäs, H. (2008). The qualitative content analysis process. Journal of Advanced Nursing, 62, 107-115. https://doi.org/10.1111/j.1365-2648.2007.04569.x

Emery, H. (2012). A global study of primary English teachers' qualifications, training and career development. (ELT Research Papers 12-08). British Council. Retrieved from https://www.teachingenglish.org.uk/sites/teacheng/files/B487_ELTRP_Emery_ResearchPaper_FINAL_web_V2 .pdf

Farrell, T.S.C. (2012). Novice-service language teacher development: bridging the gap between pre-service and in-service education and development. TESOL Quarterly, 46(3), 435-449. https://doi.org/10.1002/tesq.36 
Kaufman, R., Oakley-Browne, H., Watkins, R., \& Leigh, D. (2003). Strategic Planningfor Success: Aligning People, Performance, and Payoffs. JosseyBasslPfeiffer.

Koç, E. M. (2016). A general investigation of the in -service training of English language teachers at elementary schools in Turkey. International Electronic Journal of Elementary Education, 8(3), 455-466.

Le, V. C., \& Do, T. M. C. (2012). Teacher preparation for primary school English education: a case of Vietnam. In B. Spolsky \& Y-I. Moon (Eds.), Primary school English-language education in Asia: From policy to practice. Routledge.

Lee, H. D., \& Nelson, O. (2006). Instructional Analysis and Course Development. American Technical.

Molenda, M., Pershing, J. A., \& Reigeluth, C. M. (1996). Designing instructional systems. In R. L. Craig (Ed.), The ASTD training and development handbook (4th ed.). McGraw-Hill.

MoNE. (2015). Subject Area Competencies for English Teaching Profession Report. Retrieved from http://oygm.meb.gov.tr/meb_iys_dosyalar/2017_11/06160113_2-YYretmen_Yeterlikleri_KitabY_ingilizce_YYr etmeni_Yzel_alan_yeterlikleri_ilkYYretim_parYa_5.pdf

MoNE. (2017). Ministry of National Education Generic Competencies for Teaching Profession Report. Retrieved from http://oygm.meb.gov.tr/www/ogretmenlik-meslegi-genel-yeterlikleri/icerik/39

Munby, J. (1987). Communicative Syllabus Design. Cambridge University Press.

Noe, R. A. (1999). Employee Training and Development. McGraw-Hill.

Patton, Q. M. (2014). Nitel araştırma ve değerlendirme yöntemleri (3rd ed.). (M. Bütün, \& S. B. Demir. Transl.). Pegem Akademi.

Pratt, D. (1980). Curriculum Design and Development. Harcourt Brace.

Richterich, R., \& Chancerel, J. L. (1980). Identifying the Needs of Adults Learning a Foreign Language. Pergamon Press.

Ryan, T. G. (2019). Naturalistic observation of engagement and disengagement within professional development in education. International Online Journal of Education and Teaching, 6(1), 37-54.

Salas, E., \& Cannon-Bowers, J. A. (2001). The science of training: A decade of progress. Annual Review of Psychology, 52(1), 471-499. https://doi.org/10.1146/annurev.psych.52.1.471

Scholz, R. W., \& Binder, C. R. (2011). Environmental literacy in science and society: From knowledge to decisions. Cambridge University Press. https://doi.org/10.1017/CBO9780511921520

Taylor, P. J., O’Driscoll, M. P., \& Binning, J.F. (1998). A new integrated framework for training needs analysis. Human Resource Management Journal, 8(2), 29-50. https://doi.org/10.1111/j.1748-8583.1998.tb00165.x

TED. (2009). Turkish Education Association: Teacher Qualification Report. http://portal.ted.org.tr/yayinlar/Ogretmen_Yeterlik_Kitap.pdf

Tosriadi, T., Asib, A., Marmanto, S., \& Azizah, U. A. (2018). In-service EFL teachers' reflection as a pathway to develop teacher professionalism. International Online Journal of Education and Teaching, 5(4), 921-932. https://doi.org/10.18415/ijmmu.v5i3.140

Vagle, M. D. (2014). Crafting phenomenological research. Left Coast Press.

West, R. (1994). State of the art article - needs analysis in language teaching. Language Teaching, 27, 1-19. https://doi.org/10.1017/S0261444800007527

Wichadee, S. (2012). Factors related to professional development of english language university teachers in Thailand. Journal of Education for Teaching: International research and pedagogy, 38(5), 615-627. https://doi.org/10.1080/02607476.2013.739795

Witkin, B. R. (1984). Assessing Needs in Educational and Social Programs. Jossey-Bass.

Yıldırım, A., \& Şimşek, H. (2013). Sosyal bilimlerde nitel araştırma yöntemleri (9th ed.). Seçkin.

Yin, R. K. (2009). Case study research: Design and methods (4th ed.). Sage.

YÖK. (2018). Turkey Higher Education Qualifications Framework. Retrieved from http://tyyc.yok.gov.tr/

Zein, M. S. (2015). Factors affecting the professional development of elementary English teachers. Professional Development in Education, 42(3), 1-18. https://doi.org/10.1080/19415257.2015.1005243 
Zein, M. S. (2017). Professional development needs of primary EFL teachers: perspectives of teachers and teacher educators. Professional Development in Education, 43(2), 293-313. https://doi.org/10.1080/19415257.2016.1156013

\section{Copyrights}

Copyright for this article is retained by the author(s), with first publication rights granted to the journal.

This is an open-access article distributed under the terms and conditions of the Creative Commons Attribution license (http://creativecommons.org/licenses/by/4.0/). 